use of exhibitors. Besides the engine which supplied power in the machinery gallery last year, an engine is being erected in the new gallery which is being put up along the north side of the old South Gallery, as described in the Fournal of the Society of Arts for January 3o. A third engine will also be provided, which will drive machinery in one of the Forelgn Courts. It will thus be seen that those visitors who have mechanical tastes will be amply provided for.

As regards the prospects of applied chemistry, we are not able to speak so confidently. Probably the completeness of this portion of the show will almost entirely depend on the success of the efforts which are being made by the Society of Chemical Industry to secure a collective exhibit. The announcement made by the executive at the outset, that it was desired to show processes rather than products, is believed to have kept back many manufacturers from seeking to show specimens, while it is obvious that but few chemical processes could conveniently be carried on in an exhibition gallery. Possibly this rule might have been abrogated as regards the chemical section, and we believe that no attempt will be made to enforce it with reference to the collection of the Society of Chemical Industry, in which it is proposed that the information required shall be given by means of a collection of pictorial diagrams, exemplifying some of the more interesting or more important chemical operations.

As our readers are aware, a similar work is being undertaken by the Physical Society in the class devoted to "Philosophical Instruments and Apparatus," though in this case there will be less left for the society to do, since the principal makers of apparatus have come forward in sufficient numbers to ensure a good representative collection. The object, however, of the Society in exhibiting has been not so much to supply deficiencies, as to show the work which has been done by its own members. We believe that the Kew Observatory and the Meteorological Society will also be among the exhibitors, the latter in their old place in the grounds. Besides this, a very interesting exhibit is promised-namely, a fully fitted observatory, which we understand one of our best known makers had offered to fit up.

In the class devoted to Photography, which comes next both in the classification and in actual position in the galleries to the philosophical instruments, the Photographic Society has undertaken to form a collection of apparatus and specimens not likely to be shown by makers. It appears that the Society intend to go a little beyond the precise limits of the Exhibition, and to show a collection of examples illustrating the entire progress of photography from the inventions of Niepce and Daguerre, and it may doubtless be assumed that in so special a case no objection will be raised, especially as but a very small space indeed, and that only on the walls, will be required for what cannot fail to prove a most instructive and interesting collection.

The progress which has been made in elcctric lighting has indeed been sufficiently illustrated in the exhibitions of last and of the preceding year; in fact, the Health Exhibition offered almost the only public example of any progress at all in England. Doubtless the lesson will be repeated this year, and on a more extended scale, for we learn that considerable additions are being made to the arrangements for electric lighting of the buildings, while it is intended to use the light also for the garden illuminations, an improvement due to the energy of Sir Francis Bolton. If this idea is carried out on the plan which we understand is intended, the instantaneous lighting up of the myriad incandescent lamps by which the gardens are to be illuminated will certainly be one of the most popular, and one of the most wonderful, sights in London next summer.

The above remarks refer only to the English portion of the Exhibition. How much will be contributed by foreign countries it is not yet possible to ascertain. Thanks doubtless to the efforts which were made by certain of the members of the British Association who were in the States last year, the American Court promises to be well filled, and it must be admitted that in the present Exhibition, if we get American ingenuity well represented, we shall not very greatly miss the contributions of other countries, though we hopc, all the same, that these will not be lacking.

\section{THE RETINA OF INSECTS}

$\mathrm{T}$ might have been thought impossible for any one who 1 has studied the eyes of Arthropods to doubt that the so-called retinulæe are really the nerve-end cells of the eye, and correspond with the rods and cones of the vertebrate eye. The evidence in favour of this view accumulated by the researches of almost every observer, including such eminent authorities as Johannes Müller, Leydig, and Grenacher is so overwhelming that of late years no one has thought fit to dispute it.

Mr. Lowne has, however, at last attempted to overthrow this theory, and in a paper just published in the Trans-

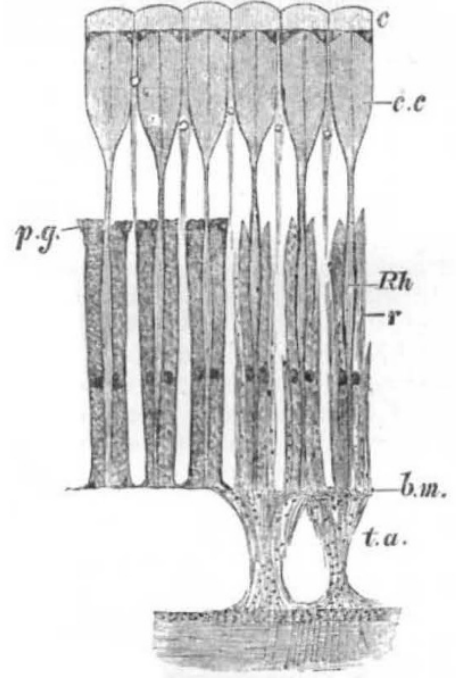

Fig 1.

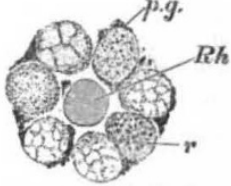

Fig 2.
FIG. x.-Section through the eye of Squilla, showing ' the $\%$ distribution of the ultimate nerve fibrils to the retinula. The Ommatidia to the of the ultimate nerve fibils to the retinulae. The Oinatidia to the left of the figure are drawn with their accompanying pigment cells ( $p \cdot g$ ) complete; in the three to the right these are in order to show more clearly the distribution or the nerve fibrils; $c$, corneal facets c.c, crystalline cone : H, rhabdom; $r$, retinula;.$m$, basilar membrane; t.a, terminal anastomosis of optic nerve fibrils supplying the retinula.

FIG. 2,- Transverse section throngh the ommatidium of Squilla, showing the seven retinula cells surrounding the central rhabdom. The retinula are seen to possess a considerable amount of granular pigment, which is unevenly distributed in the different cells.

actions of the Linnean Society, vol. ii. part ii., on "The Compound Vision and the Morphology of the Eye in Insects," has brought forward certain statements to prove that all the parts of the eye in front of the basilar membrane are dioptric, whilst the true (?) retina is situated behind it.

To one who has been devoting considerable time and attention to the eye of Arthropoda, this proposition is particularly striking and unexpected, and many points at once occur which show that it is untenable.

In the first place it is untenable because we have ample evidence to show that the original theory is the true one. The nerve-end cells throughout the animal kingdom have certain definite characteristics. They are the cells in which the ultimate fibrils of the optic nerve terminate, and no nerve fibrils have ever been seen to leave them to supply otler parts of the eye; and, in the second place, 
they are always pigmented either by a diffuse fluid "retinal purple," or by pigment in granules, or both.

In both these particulars the retinule of Arthropoda resemble the nerve-end cells of other animals.

It is hardly necessary to point out that Lcydig, Max Schultz, Grenacher, and many others, have traced the optic nerve fibrils to the retinule. I have in my possession scveral series of preparations showing this both in insects and Crustacea, and any onc can readily see this for himself by making even clumsy sections through the eye of Squilla.

In Fig. 1 I have figured the nerve fibrils of the eye of Squilla perforating the basement membrane and entering the retinule, and in Fig. 2 a transverse scction through the rhabdom and retinulie showing their relat ve position and numbers.

A special feature of the retinula is that it is always pigmented. In specimens hardened in spirit a granular pigment may be seen in the retinula cells, which is usually of a light-brownish colour and very unevenly distributed (Fig. 2). But in addition to this granular pigment, the retinula contain a true retina purple, which fades upon exposure to the light. This was discovered in 1864 by Leydig ${ }^{1}$ in the following genera of Insecta :I'rocrustes, Scarabacus, and l'ieris, and in Astacus among the Crustacea. I have also seen it in Musca vomitoria, and have now no doubt that it exists in the Arthropod eye gencrally.

So far, then, I think it must be admitted that both anatomical and physiological considerations tend to prove that the retinula is the nerve-end cell of the Arthropod eye.

When we turn to morphology, too, we have confirmatory cvidence that this is the case.

In the ocellus of the water-beetle larva the retina is a simple cup of pigmented hypodermis celis, in which the optic nerve fibrils may be readily scen to terminate. These cells are most certainly homologous with the retinula cells of the so-called "compound" Arthropod eye, as has been already shown by Grenacher in his important treatise, "Untersuchungen über das Sehorgan der Arthropoden " and elsewhere, and confirmed by the more recent researches of Lankester and Bourne upon the eyes of Limulus and the scorpions.

The rescarches of Claparcde and Weismann on the development of the eye of Arthropods confirms the deductions of morphology, by proving that the cells which ultimately form the retinule are specially modified hypodermis cells, and at an carly stage come into connection with optic nerve fibrils. If any further evidence were required to confirm tnis homology it can be readily obtained by studying the eyes of very young cockroaches, in which the retinule at the periphery of the eyc are formed from specially modificd and deeply pigmented hypodermis cells.

But it is tedious and unnecessary bringing evidence of this kind to confirm a thcory which is already fully estatblished in the minds of most naturalists. In fact we have here an instance in which morphology, physiology, com parative anatomy, and development combine to establish an homology, and consequently we must definitcly assert that the retinule are the nerve-end cclls throughout the Arthropoda. But what is the meaning of Lowne's bacillar layer behind the basilar membrane? and does it exist in all $\Lambda$ rthropods?

It is perfectly true that behind the basilar in many Diptera, Coleoptera, Lepidoptera, and Hymenoptera there is a layer composed of a number of small cylindrical masscs which has a superficial resemblance to the rods of the Vertebrate eye, but Mr. Lowne did not discover this layer in any sense of the word, for it was perfectly well known to Leydig, who figured it in Formica rula, Dytiscus marginalis, and Sphin.x ligustri (vide I.eydig's 'Tafeln,

\footnotetext{
"Lydis, "Das Ange der Clie.turthiere." Tübingen, 1804 .
}

viii. ix. x.). The little cylindrical masses cannot be regarded as cells, nor rods, nor bacilli, for each one of them is composed of a very fine reticulum of nerve fibrillit which is in direct communication with the optic nerve fibrils bchind, and the terminal anastomosis of the optic nerve fibres in front. In fact, these "bacilli" of Lowne are connected with nerve fibrils on both sides, and thus differ from "nerve-end cells" in one of their two fundamental characters.

Very often, too, this layer is quite devoid of any pigment ( $\Lambda$ pis, Eristalis, Bombyx, Squilla, \&c.), and no one has ever yet been able to demonstrate the presence of retina purple in this region.

Another important difficulty in the way of accepting this theory, too, is the fact that this layer is not always present (Periplaneta, Nepa), and in itl Crustacea and many insects it cannot be divided into separate bacilli.

I have lately paid considerable attention to this part of the optic tract, but must defer a fuller explanation of the meaning of it until I am able to publish my paper in the Quarterly 7ournal of Microsiopical Science, when I shall be able to illustrate my researches by several figures. To summarise, however, the evidence against this layer being composed of nerve-end cells: We find that it is certainly not homolngous with the retina of other animals; optic nerve fibrils both enter and leave it ; it is devoid of retina purple or of any other form of pigment in many Arthropods, and finally it is absent as a bacillar layer in many insects and in all Crustacea. In fact we can bring as much evidence to prove that this is not the retina as we can to prove that the retinule are the true nerve-end cells.

At the conclusion of his paper Mr. Lowne says, in referring to a recent memoir of Justus Carriere of Strassburg, "He remains, however, a disciple of established views, and has not given the retinal layer nearly so much attention as it deserves." I have given the retinal layer as "much attention as it deserves," and must also claim to remain a "disciple of established views."

$$
\text { SYDNEY J. HICKSON }
$$

\section{RORAIMA}

A TELEGRAM has been received at Kew giving the welcome news that Mr. Everard F. im Thurn has at last ascended Roraima. This has been the cherished object of botanical exploration in South America for the last quarter of a century. The expenses of Mr. im Thurn's expedition have been borne in equal shares by the Government grant of the Royal Society and the Royal Geographical Society.

The latest news from Mr. im Thurn was in a letter dated December 6 from the south side of the mountain, and the following passage describes the position immediately before the final attack:-

"Before we came to Roraima itself we had four days walking through a purely savannah, but most glorious country, and over splendid mountain passes, guided by an Arecoona who said, villain that he is, that he know the way to Roraima. But at a village marked on the map as Ipelemonta, on the Aroopa River, and with a considerable mountain pass still betwcen us and Roraima, our villain guide at last admitted that the road for some distance had becn quite new to him, and that he now knew not how to proceed further. However, at last we procurcd a guide, and came, in some four hours, out of our difficulties at I pelemonta (its rcal name, by the way, is Toorarking), into this inconceivably magnificent valley, and are installed in a village on the actual southern slopes of Roraima itsclf.

Yesterday Perkins and I ascended the slope of Roraima to a height of 5600 feet to a most beautiful spot - a very garden of orchids and most beautiful and strange plants. To-morrow, after despatching the bearer of this scrawl, we 